\title{
Analysis of soil water dynamics in an agroforestry system based on detailed soil water records from time-domain reflectometry
}

\author{
N.A. Jackson and J.S. Wallace \\ Institute of Hydrology, Wallingford, OX10 8BB, United Kingdom \\ e-mail address for corresponding author: n.jackson@ioh.ac.uk
}

\section{Abstract}

Time domain reflectometry [TDR] was used to investigate the spatial and temporal variation in surface soil water dynamics under a number of types of vegetation, including both trees and crops grown in isolation, and grown together as an agroforestry system. The installation and operation of this technique are presented, and discussed in terms of its suitability to monitor rapid fluctuations in soil-water content in a spatially heterogeneous system such as that described in this experiment.

The relatively small sampling volume of each of the TDR waveguides permitted discrete measurements to be made of soil water content $\left(\theta_{\mathrm{v}}\right)$. In the tree-only and tree+crop treatments, this revealed considerable variation in $\theta_{\mathrm{v}}$ resulting from spatial redistribution of rainfall under the tree canopies, with a significant input to soil close to the base of the trees being made by stemflow, i.e. water intercepted by the tree canopy and channelled down the stem.

Over the experimental period (one rainy season) the TDR data suggested that net recharge to the soil profile in the sole crop system was $53 \mathrm{~mm}$, almost $75 \%$ more than occurred in either of the two treatments containing trees, reflecting greater rainfall interception by the tree canopies.

\section{Introduction}

The experiment reported here formed part of a larger investigation of water use in an agroforestry system. Such water use studies are rare (Ong et al., 1991), and tree/crop systems are often spatially complex in nature, with both the tree and crop canopies affecting rainfall distribution and input to the soil surface. Furthermore, in addition to most crop roots being concentrated in the top $0.5 \mathrm{~m}$, Toky and Bisht (1992) found that root density was highest in the top $0.3 \mathrm{~m}$ for ten out of twelve agroforestry tree species investigated. Observations made as part of the larger field experiment confirmed that this was true for the tree and crop combination used in this study. For these reasons, time-domain reflectometry (TDR) was used to measure the rapidly occurring changes in surface soil water content over short lateral distances $(<1 \mathrm{~m})$ and depths $(0-0.4 \mathrm{~m})$, providing data for future modelling of the soil water balance.

TDR has been used for many years in the telecommunications industry for locating breaks in coaxial cable. Several authors have demonstrated the relationship between a soil's dielectric constant $\left(K_{\mathrm{a}}\right)$ and the volumetric water content $\left(\theta_{\mathrm{v}}\right)$, and a more complete treatment of the theory of this relationship can be found elsewhere (Davis and Chudobiak, 1975; Topp and Davis, 1985; Ledieu et al., 1986; Zegelin et al., 1992). One advantage of TDR over many other forms of soil water measurement is that it lends itself to automated control and multiplexing, so that continuous data can be collected, with a frequency necessary to measure the dynamic nature of surface soil water storage.

Several authors have used TDR to investigate spatial and temporal variation in soil water content under maize (van Wesenbeeck and Kachanoski, 1988; Zhai et al., 1990; Coelho and Or, 1996); they found persistent differences 'on' and 'off' crop rows. Similarly, several TDR studies have shown the effect that forest canopies impose on soil water content, both in semi-arid (Breshears et al., 1997) and temperate situations (Nyberg, 1996; Ladekarl, 1998). However, few, if any, studies have been carried out using TDR to examine spatial and temporal variation in soil water content in combined tree and crop agroforestry systems. 


\section{Materials and methods}

\section{SITE DESCRIPTION AND EXPERIMENTAL DESIGN}

The experiments were conducted at the Machakos field station of the International Centre for Research in Agroforestry (ICRAF) in Kenya. The station is situated about $80 \mathrm{~km}$ south-east of Nairobi at $1^{\circ} 33^{\prime}$ South, $37^{\circ} 8^{\prime}$ East, at about $1560 \mathrm{~m}$ altitude (Kibe et al., 1981). The site has a south to south-west facing slope of about $22 \%$ and was covered by scrub dominated by Acacia $s p$. before the experiment was established in 1991. The slope runs downhill to the Maruba river about $200 \mathrm{~m}$ below the site. The Machakos field station is typical of the surrounding Kenyan uplands (Scott $e t$ al., 1971).

The soil consists of a series of shallow $(0.2$ to $2 \mathrm{~m})$ reddish-brown to brown well-drained luvisols (FAO soil classification) varying in clay content over the profile, with a number of distinct horizons (Kibe et al., 1981; Huxley et al., 1989). Water release curves for the surface $(0-0.4 \mathrm{~m})$ soil layers at the field site, were determined from intact soil cores (Soil Survey, UK). These confirmed that the soil was a typical sandy clay loam and was unlikely to exhibit soil water contents lower than $0.05 \mathrm{~m}^{3} \mathrm{~m}^{-3}$, the threshold below which most commonly used TDR calibration equations are unable to determine $\theta_{\mathrm{v}}$ accurately (Zegelin et al., 1992).

The soil is underlain by layers first of weathered and then coherent rock (gneiss) at varying depths. A band of very shallow soils $(0.2$ to $0.6 \mathrm{~m}$ deep) ran across the site from the top north-west corner towards the bottom southeast corner. Soils were generally deeper $(0.7$ to $1.5 \mathrm{~m})$ above and below this band (Wallace et al., 1995).

This experiment formed part of an agroforestry trial conducted by ICRAF and the Institute of Hydrology at Machakos established in October 1991, details are given elsewhere (Wallace $e t$ al., 1995). Briefly, plots of size $20 \mathrm{~m} \times 20 \mathrm{~m}$ were planted either with Grevillea robusta, a popular upperstorey tree species in East Africa (ICRAF, 1995), grown on their own $\left(T_{d}\right.$ treatment), maize planted on its own $\left(\mathrm{C}_{\mathrm{g}}\right.$ treatment), or the two components grown together $\left(C T_{d}\right.$ treatment). These planting arrangements are shown in Fig. 1. Maize was planted after the onset of the rains, when the entire ground surface was prepared with hand hoes, in rows $1 \mathrm{~m}$ apart, $0.3 \mathrm{~m}$ between plants. The tree canopies were regularly pruned during the course of the experiment following local farming practice, maintaining similar sized canopies on all trees.

\section{INCIDENT RAINFALL}

Annual rainfall has a bi-modal distribution, with a short rainy season of $265 \mathrm{~mm}$ usually lasting from late October to late December, and a longer rainy season of $345 \mathrm{~mm}$ running from late March to the end of May. Monthly rainfall peaks in April and November and there is little rainfall in July, August and September. Machakos district has a large inter-annual variation in monthly and seasonal rainfall. The climate is on the boundary between sub-humid and semi-arid (Huxley et al., 1989).

Incident rainfall was measured using a tipping-bucket raingauge ( $200 \mathrm{~mm}$ diameter) positioned uphill from the plots and approximately $20 \mathrm{~m}$ from the nearest trees. Rainfall was measured every 10 minutes and cumulative hourly values were stored on a data logger (Campbell 21x, Campbell Scientific Instruments, USA).

\section{TIME DOMAIN REFLECTOMETRY: INSTALLATION}

The TDR system (Soil Moisture Corp. Trase ${ }^{\mathrm{Tm}}$ System I, Goleta, CA, USA) installed in this agroforestry trial used buriable waveguides or 'sensors', of a three-wire design, $0.2 \mathrm{~m}$ long, with a space of $15 \mathrm{~mm}$ between the wires. Three-wire probes simulate a coaxial line directly and therefore do not need additional impedance matching transformers or 'baluns' (Topp, 1992). A sensor length of $0.2 \mathrm{~m}$ was chosen to provide an acceptable degree of resolution in $\theta_{\mathrm{v}}\left(0.01 \mathrm{~m}^{3} \mathrm{~m}^{-3}\right)$ when used with long $(30 \mathrm{~m})$ cables. Using shorter sensors with long cable lengths would have introduced an underestimation of $K_{\mathrm{a}}$ and hence reduced the resolution of estimates of $\theta_{v}$ (Heimovaara, 1993).

60 TDR sensors were installed on 5 April 1994 by digging small soil pits down-slope of the sensors' desired location (see Fig. 1). The TDR sensors were multiplexed to a central signal processing and recording unit. Waveforms from the sensors were inspected manually to ensure that each was working correctly before the soil from each pit was refilled carefully and compacted to approximate the undisturbed soil bulk density. Each TDR 'location' comprised a group of four sensors, inserted horizontally into the upslope soil face, at depths $0.05,0.15,0.25$ and $0.35 \mathrm{~m}$.

Three sensor groups ( 12 sensors) were located in one of the $\mathrm{C}_{\mathrm{g}}$ plots, each group positioned midway between the rows of maize, each sampling the same area of soil. In each of the $T_{d}$ and $C T_{d}$ plots, six sensor groups (24 sensors) were installed at various distances $(0.3,1.0,1.5,1.8,2.0$ and $2.5 \mathrm{~m}$, see Fig. 1) from the base of trees of average height, basal diameter and projected canopy area.

The radial distances of the TDR sensor groups meant that the soil water contents measured by each group were representative of a different sized fraction of the area occupied by each tree. Therefore, the overall area $\left(12 \mathrm{~m}^{2}\right)$ was subdivided into concentric rectangular zones around the tree, with the inner and outer boundaries of each zone given by the midpoints between the radial distances of each of the TDR sensor groups (see Table 1). Each zone had the same proportions as the $4 \times 3$ rectangle occupied by each tree. The areal average soil water content was therefore a weighted mean value, using the percentage area of each zone as the weighting factor.

The limited number of channels available to multiplex the TDR sensors prevented spatial replication within the 


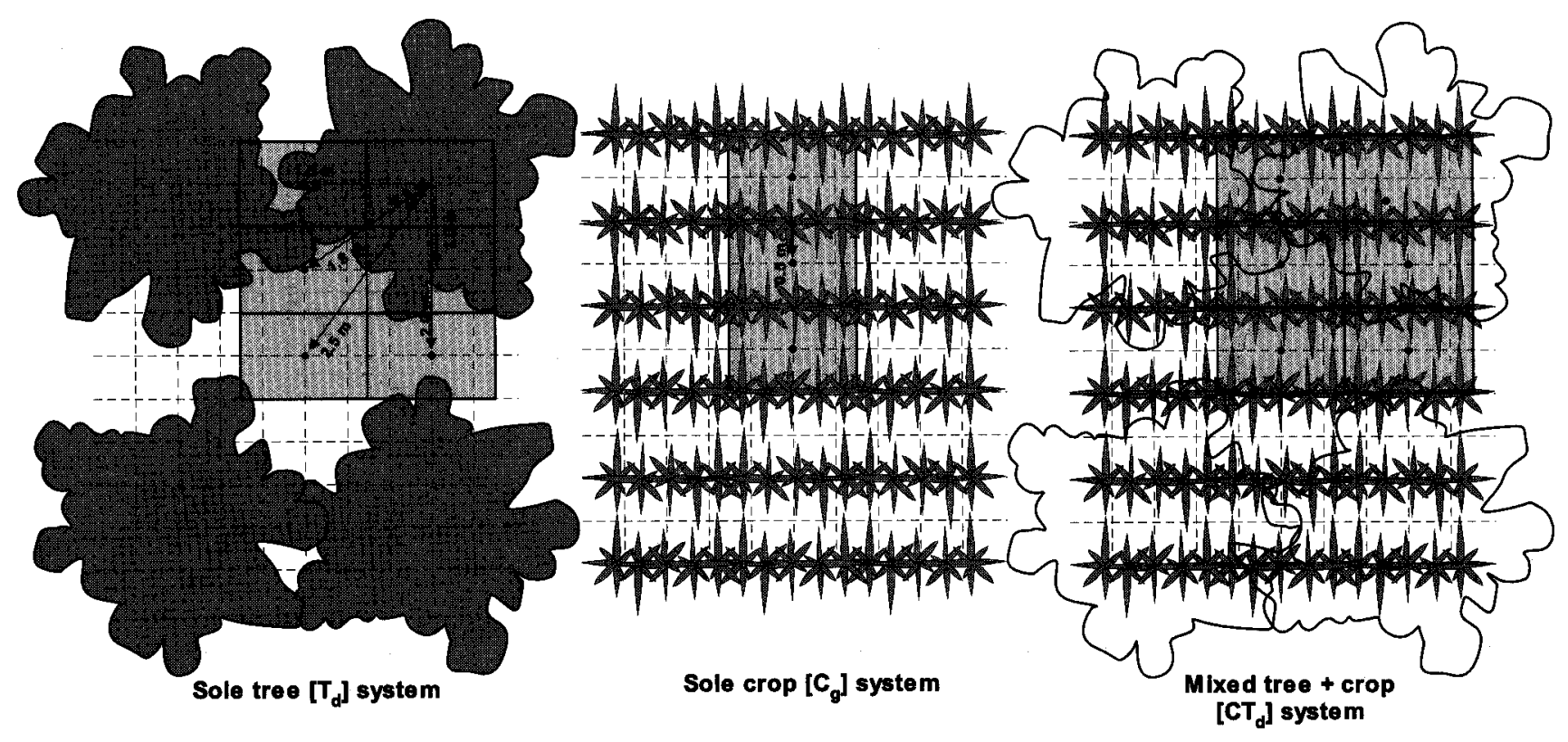

Fig. 1. A schematic representation of the layout of the three treatments in which TDR sensors, throughfall and stemflow gauges were deployed. Each of the small squares is $0.5 \mathrm{~m} \times 0.5 \mathrm{~m}$, and each of the shaded blocks is $1.5 \mathrm{~m}^{2}$.TDR sensors mere deployed midway between maize rows in sole-planted maize. Otherwise, TDR sensors were deployed at various radial distances (shomn) from the base of a tree in both the sole-tree and tree+crop treatments. Gauges measuring rainfall interception mere placed in positions identical to the TDR sensors in all three treatments.

three treatments, but to attempt to account for possible differences in surface soil texture or composition, the entire network of TDR sensors was moved three times during the experiment and reinstalled in the same arrangement (i.e. between crop rows and/or around trees). Each time the sensor network was relocated, the same trends in soil water content were observed, suggesting that these were due to treatment effects rather than variations in soil conditions.

All sixty TDR sensors were logged hourly from 5 April 1994 onwards. Waveforms from each sensor were inter- preted automatically by the software in the central processing unit and stored as volumetric water contents $\left(\theta_{v}, \mathrm{~m}^{3} \mathrm{~m}^{-3}\right)$. The data were downloaded every few days using a portable computer, and were inspected manually to remove occasional spurious readings. The noise component common to TDR data was reduced by taking a 7point moving average of the hourly data, following the procedures of Zegelin et al. (1992), and Baker and Spaans (1994). The variance between the moving average and the measured water contents was typically less than $0.5 \mathrm{~mm}$. Volumetric water contents $\left(\theta_{\mathrm{v}}\right)$ were converted to storage

Table 1. The way in which the $12 \mathrm{~m}^{2}$ occupied by each tree in the $T_{d}$ and $C_{d}$ treatments $(4 \times 3 \mathrm{~m}$ planting $)$ was subdivided into concentric zones, the boundaries of which were the midpoints between the TDR sensors. The percentages of the total area of each of the zones were used to obtain weighted areal average soil water contents.

\begin{tabular}{lllll}
\hline $\begin{array}{l}\text { Radial distance } \\
\text { of TDR sensor }\end{array}$ & Inner boundary & Outer boundary & $\begin{array}{l}\text { Rectangular area of } \\
\text { zone around tree }\end{array}$ & $\begin{array}{l}\text { Proportional } \\
\text { land area }\end{array}$ \\
\hline$(\mathrm{m})$ & $(\mathrm{m})$ & $(\mathrm{m})$ & $\left(\mathrm{m}^{2}\right)$ & $(\%)$ \\
\hline 0.3 & $0.00^{\mathrm{b}}$ & 0.65 & 0.81 & 6.76 \\
1.0 & 0.65 & 1.25 & 2.19 & 18.24 \\
1.5 & 1.25 & 1.65 & 2.25 & 18.75 \\
1.8 & 1.65 & 1.90 & 1.59 & 13.25 \\
2.0 & 1.90 & 2.25 & 2.88 & 24.00 \\
2.5 & 2.25 & 2.50 & 2.28 & 19.00 \\
\hline
\end{tabular}

a Each zone had the same proportions as the $4 \times 3$ rectangle occupied by each tree.

b The innermost zone was considered to stretch from the centre of the tree to the midpoint between the sensors at 0.3 and $1.0 \mathrm{~m}$. 
values $(S)$ in $\mathrm{mm}$, integrating the values from each of the four sensor depths in each $0.4 \mathrm{~m}$ profile.

\section{TIME DOMAIN REFLECTOMETRY: CALIBRATION}

The empirical equation of Topp et al. (1980) relating $K_{\mathrm{a}}$ and $\theta_{\mathrm{v}}$ :

$$
\begin{array}{r}
\theta_{v}=-5.3 \times 10^{-2}+2.92 \times 10^{-2}\left(K_{a}\right)- \\
5.5 \times 10^{-4}\left(K_{a}\right)^{2}+4.3 \times 10^{-6}\left(K_{a}\right)^{3}
\end{array}
$$

was shown to work in various soils of different textures and compositions, although more recent attempts have been made to derive TDR calibrations that incorporate soil physical aspects (Ledieu et al., 1986). The TDR system in the present study uses a copyrighted 'lookup table' (Soil Moisture Corp., 1991) based on time delay factors and subsequent $K_{\mathrm{a}}$ values. The Trase ${ }^{\mathrm{TM}}$ calibration table follows the empirical model of Topp et al. (1980) closely but allows for variation in soil type (Skaling, 1992). Zegelin et al. (1992) stated that the 'universal' empirical calibration derived by Topp et al. (1980) worked well in almost all soils except those with a significant organic component; however, even in light textured soils, there might be a systematic deviation from the relation below soil water contents of $0.05 \mathrm{~m}^{3} \mathrm{~m}^{-3}$ because the dielectric component of individual soil components then becomes important.

To determine whether the 'built-in' Trase ${ }^{\mathrm{TM}}$ lookup table provided an accurate enough estimation of soil water content at Machakos, it was compared with the Topp et al. (1980) calibration, using both intact cores of soil taken from the field $(125 \mathrm{~mm}$ diameter, $250 \mathrm{~mm}$ deep) and prepared 'test cells' filled with dried field soil $(60 \mathrm{~mm} \times 60$ $\mathrm{mm} \times 250 \mathrm{~mm}$ ) repacked to the mean soil bulk density. The test cells were wetted gradually from beneath by placing them on a bed of wet sand until they reached the desired volumetric water content. The soil water content of the test cells was measured gravimetrically by drying the soil at $80^{\circ} \mathrm{C}$ until constant weight had been determined. The soil water content was then expressed volumetrically $\left(\mathrm{m}^{3} \mathrm{~m}^{-3}\right)$.

The TDR signals from both the cores and the test cells were measured with the same type of waveguide that were used in field measurements, inserted vertically into the soil. The dielectric constant of each test cell or core was determined by the TDR central unit, and these $K_{\mathrm{a}}$ values were used to calculate volumetric water contents $\left(\mathrm{m}^{3} \mathrm{~m}^{-3}\right)$ using both the Trase ${ }^{\mathrm{TM}}$ system lookup table, and Eqn. 1 . The values of $\theta_{\mathrm{v}}$ calculated by each method were plotted against oven-dried determinations of $\theta_{\mathrm{v}}$ and the relationships are shown in Fig. 2.

Both methods estimated $\theta_{\mathrm{v}}$ very well, accounting for more than $96 \%$ of the scatter, and with sample variances around the 1:1 relationship of 0.01 and $0.03 \mathrm{~m}^{3} \mathrm{~m}^{-3}$ for the Topp and Trase $^{\mathrm{TM}}$ calibrations, respectively. Given that the difference between the two methods was similar to the limit of sensitivity of the instrument $\left(0.01 \mathrm{~m}^{3} \mathrm{~m}^{-3}\right)$, and to

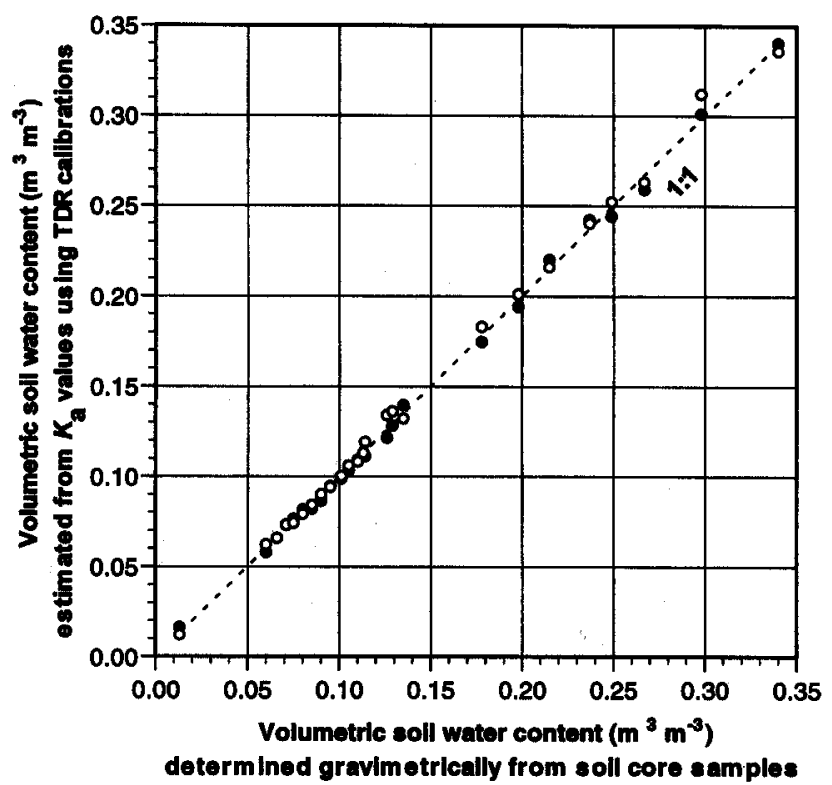

Fig. 2. Comparison between soil water contents determined gravimetrically and estimated using the built in Trase ${ }^{\mathrm{TM}}(0)$ and Topp (•) $T D R$ calibrations. Data were obtained from repacked soil in laboratory test cells and from intact soil cores taken from the field.

avoid an extra step in data analysis, the Trase ${ }^{\mathrm{TM}}$ method was used to estimate $\theta_{\mathrm{v}}$.

\section{CANOPY RAINFALL INTERCEPTION}

To compare changes in surface soil water content to varying water input, matching measurements of rainfall interception by the tree and crop canopies were made. For reasons of cost, manually recorded rather than tipping bucket raingauges were used. These were measured after every rainfall event. Siting the gauges too close to the TDR sensor groups would have rendered the purpose of the study impossible, i.e. recording rapid changes in surface soil moisture.

Therefore a matching interception gauge for each TDR sensor group was installed in an equivalent position around a tree of equal height, basal diameter and projected canopy area, no more than $3 \mathrm{~m}$ away (or $\sim 2 \mathrm{~m}$ further along the same crop rows in the case of the $C_{g}$ plots). As with the TDR sensor groups, the network of interception gauges was moved at regular intervals to other trees in the plots as a form of temporal replication.

Even with canopies pruned to a consistent size and shape, the possibility remains of small scale variation in interception between tree canopies, e.g. due to 'canopy drip' from branches directly over the raingauge. However, the results of a larger interception study in the same plot (Jackson, 1999) determined that although there was significant variation in interception at different radial positions away from the tree, the variation between gauges at similar positions was low (less than $5 \%$ ). 


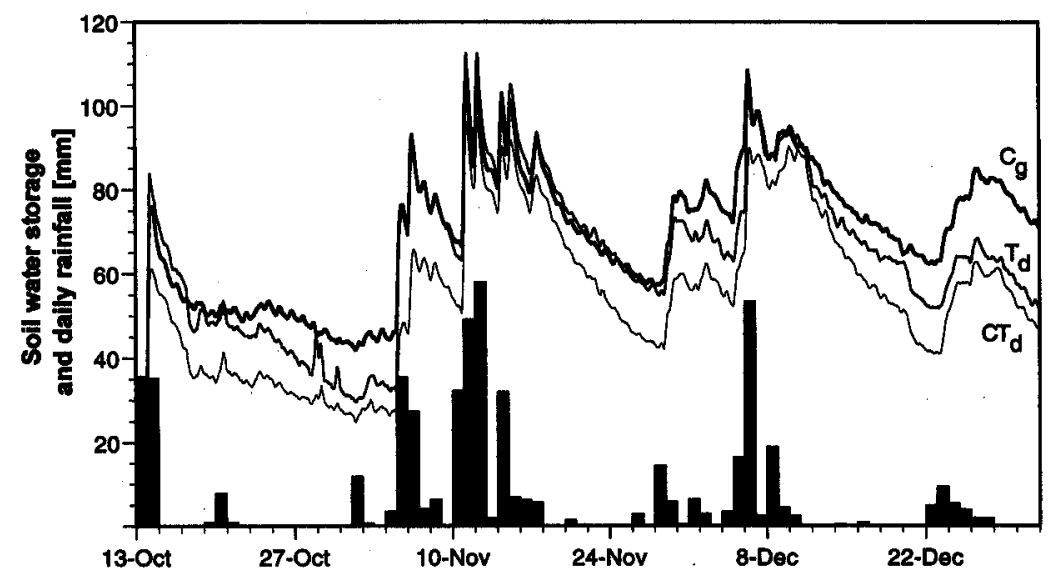

Fig. 3. Changes in the integrated mater storage $(S)$ in the top $0.4 \mathrm{~m}$ soil profile in the three treatments, $C_{g}, T_{d}$ and $C T_{d}$ (thick to thin lines, respectively) between 13 Oct and 31 Dec, 1994. The data are shown as weighted means of the integrated $0.4 \mathrm{~m}$ profiles (see text for details) at all six $T D R$ positions in the $T_{d}$ and $C T_{d}$ treatments (see Fig. 1), and the mean of the three $T D R$ positions in the $C_{g}$ plot. Corresponding daily rainfall is shown below the TDR graph.

One effect of the tree canopies, in particular, is to channel some of the rainfall intercepted by the foliage down the trunk and into the soil immediately surrounding the base of the tree. Obviously, the degree to which this occurs is influenced strongly by the shape of the tree canopy but in the case of Grevillea the volumes of water involved can be substantial. Nine stemflow gauges were installed on trees in each of the $T_{d}$ and $C T_{d}$ plots. The gauges comprised a flexible plastic collar which was sealed to the trunk of the tree with a non-toxic silicone compound about $0.75 \mathrm{~m}$ above the ground. The collars drained to plastic jerry-cans of $35 \mathrm{l}$ capacity, which were measured at the same time as the interception gauges.

Observations made on trees without gauges showed that when the stemflow water reached the soil surface, all infiltrated close to the base of the tree $(<0.5 \mathrm{~m})$, i.e. well within the $1.5 \mathrm{~m}^{2}$ block of soil containing the tree shown in Fig. 1. On this basis, stemflow was converted to $\mathrm{mm}$ equivalents using a distribution area of $1.5 \mathrm{~m}^{2}$, and was combined with the throughfall measurements made over this block of soil.

\section{Results and discussion}

\section{TREATMENT EFFECTS ON 0-0.4m PROFILE WATER STORAGE $(S)$}

It was important to quantify the surface soil water dynamics of the agroforestry system in comparison with the conventional tree-only and crop-only alternatives. Farming practices in semi-arid regions, such as the maize-only system used in this study, often use less than $50 \%$ of the rainfall input to the soil surface (Ong et al., 1991; Wallace, 1991), the rest being lost gradually during the dry interseasonal periods under conventional crop-only systems, by soil evaporation from the bare soil, and through drainage.
In a simultaneous study (Jackson et al., 1999), neutron probe measurements made over the entire profile $(0-2 \mathrm{~m})$ showed that the soil below $0.4 \mathrm{~m}$ hardly recharged at all following rainfall. In addition, Smith et al. (1999) found that more than $50 \%$ of the rooting system of the Grevillea trees was concentrated in the top $0.4 \mathrm{~m}$ of soil. Our data suggest that these roots utilised much if not all of the incoming rainfall during these seasons, and prevented the lower soil layers from recharging. For these reasons, rapid changes in the $0-0.4 \mathrm{~m}$ soil layer measured by the TDR sensors are particularly important.

The mean $(0-0.4 \mathrm{~m})$ water storage values for the $C_{g}, T_{d}$ and $\mathrm{CT}_{d}$ treatments are plotted against time in Fig. 3, for part of the 1994 short rains. The data are presented as averages of three sensor groups (in the $\mathrm{C}_{\mathrm{g}}$ treatment) or weighted areal averages of six groups in the $T_{d}$ and $C T_{d}$ treatment. Initial water storage just before the onset of the rains (12 Oct 1994) was similar for all three treatments, at $18.4 \pm 1.7 \mathrm{~mm}, 18.0 \pm 1.5 \mathrm{~mm}$ and $18.6 \pm 0.3 \mathrm{~mm}$ for the $\mathrm{CT}_{\mathrm{d}}, \mathrm{T}_{\mathrm{d}}$ and $\mathrm{C}_{\mathrm{g}}$ plots, respectively.

Rainfall interception was greater under the tree canopies than under the sole crop (Table 2), leading to lower soil water inputs in the $T_{d}$ treatment, and the lowest occurring in the $\mathrm{CT}_{\mathrm{d}}$ treatment, where increases in water storage following rainfall were on average $15 \%$ lower than in the $C_{g}$ plots $(p \leq 0.05)$. Hourly increases in water storage in the $\mathrm{CT}_{\mathrm{d}}$ plots ranged between 0.1 and $6.8 \mathrm{~mm} \mathrm{~h}^{-1}$ and were lower during each rainfall event than those for the $T_{d}$ and $\mathrm{C}_{\mathrm{g}}$ plots, which ranged from 0.1 to $9.3 \mathrm{~mm} \mathrm{~h}^{-1}$, and from 0.1 to $8.1 \mathrm{~mm} \mathrm{~h}^{-1}$, respectively ( $p \leq 0.05$ ).

After rainfall, there were distinct differences between treatments in terms of the rate of decrease in soil water content. The absolute drying rates for the agroforestry plots, ranged between 0.1 and $1.7 \mathrm{~mm} \mathrm{~h}^{-1}$ over the period of study. These rates were lower after each rainfall event than those for the sole tree plots, and sole crop plots, 
Table 2. Cumulative rainfall $\left(\Sigma P_{g}\right)$ and net rainfall (combined throughfall and stemflow: $\left.\Sigma P_{n}\right)$ in the $\mathrm{C}_{\mathrm{g}}, \mathrm{T}_{\mathrm{d}}$ and $C \mathrm{~T}_{\mathrm{d}}$ treatments, recorded between Oct 12 and Dec 31, 1994. Data are given as $\mathrm{mm}$ of water and $\Sigma P_{n}$ as a percentage of $\Sigma P_{g}$.

\begin{tabular}{lcccccc}
\hline & \multicolumn{4}{c}{ Cumulative net rainfall $\left(\Sigma P_{n}\right)$ below tree/crop canopies } \\
\hline $\begin{array}{l}\text { Cumulative rainfall } \\
\text { off-plot }\left(\Sigma P_{\mathrm{g}}\right)(\mathrm{mm})\end{array}$ & $\begin{array}{c}\text { Sole crop, } \mathrm{C}_{\mathrm{g}} \\
(\mathrm{mm})\end{array}$ & $\begin{array}{c}\text { Sole tree, } \mathrm{T}_{\mathrm{d}} \\
\left(\% P_{\mathrm{g}}\right)\end{array}$ & $(\mathrm{mm})$ & $\left(\% \Sigma P_{\mathrm{g}}\right)$ & $\begin{array}{c}\text { Tree+crop, } \mathrm{CT}_{\mathrm{d}} \\
(\mathrm{mm})\end{array}$ & $\left(\% \Sigma P_{\mathrm{g}}\right)$ \\
\hline 512 & 463 & $90 \%$ & 421 & $82 \%$ & 390 & $76 \%$ \\
\hline
\end{tabular}

which ranged from 0.1 to $2.4 \mathrm{~h}^{-1}$, and from 0.1 to $2.6 \mathrm{~h}^{-1}$, respectively $(p \leq 0.05)$.

The 'rising' and 'falling' portions of the TDR time courses were separated and are presented in Fig. 4 as cumulative gains and losses of surface soil water in each of the treatments. Throughout the period, water storage was greatest in the $\mathrm{C}_{\mathrm{g}}$ treatment at $414 \mathrm{~mm}$, slightly lower in the $T_{d}$ plots at $402 \mathrm{~mm}$, and lowest when the trees and crops were grown together in the $\mathrm{CT}_{\mathrm{d}}$ treatment at $346 \mathrm{~mm}$.

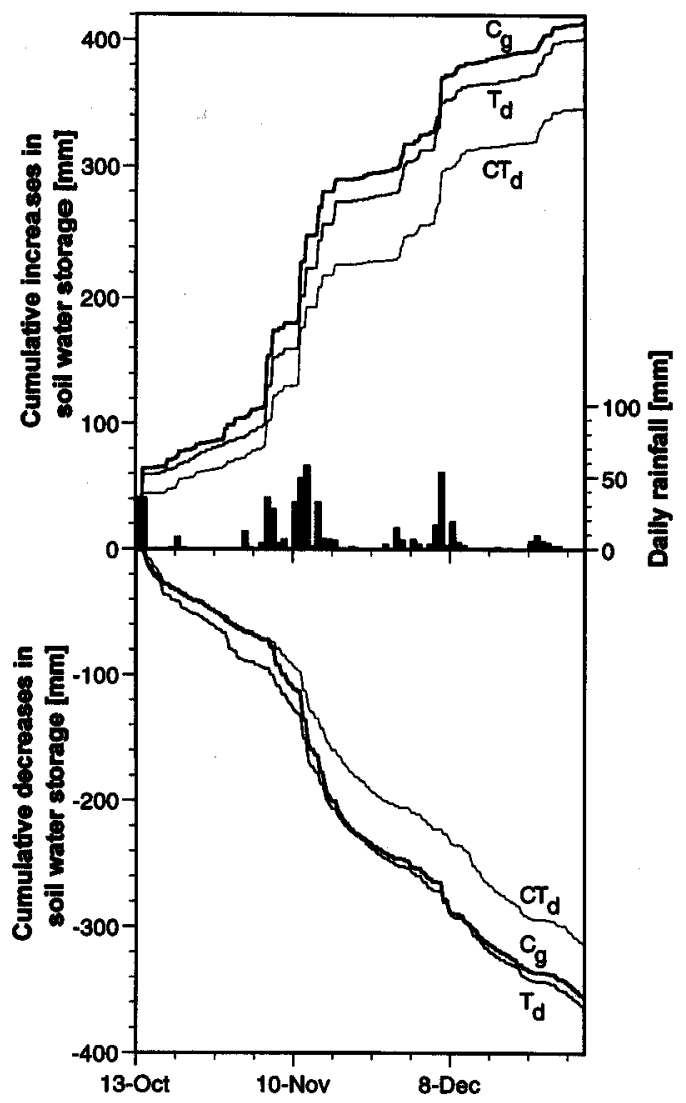

Fig. 4. Data from Fig. 3 plotted in terms of cumulative gains and losses in mater against time in the $C_{g}, T_{d}$ and $C T_{d}$ profiles (thick to thin lines, respectively) betmeen 13 Oct and 31 Dec, 1994. Corresponding daily rainfall is shown below the TDR graph.
Cumulative losses of water were initially greater in the $T_{d}$ plots than in either the $C_{g}$ or $C T_{d}$ plots, which may reflect higher transpiration rates from the larger trees in the $T_{d}$ plots (Lott et al., 1997). Large gains in water in the $\mathrm{C}_{\mathrm{g}}$ plots during this initial period, with correspondingly small losses, may be due in part to the fact that the $\mathrm{C}_{\mathrm{g}}$ maize plants were quite small and transpirational demand was low. As the $\mathrm{C}_{\mathrm{g}}$ crop cover increased cumulative losses more closely matched those from the $T_{d}$ treatment.

By the end of the period studied, the cumulative losses from the $C_{g}, T_{d}$ and $C T_{d}$ plots were $359 \mathrm{~mm}, 364 \mathrm{~mm}$ and $314 \mathrm{~mm}$, respectively. By the end of the rainy season (late Dec 94), net profile storage increased by $55 \mathrm{~mm}$ in the $\mathrm{C}_{\mathrm{g}}$ plots, by $38 \mathrm{~mm}$ in the $T_{d}$ plots and by $32 \mathrm{~mm}$ in the $C T_{d}$ plots. Cumulative rainfall $\left(\Sigma P_{\mathrm{g}}\right)$ during the period shown was $512 \mathrm{~mm}$.

\section{SPATIAL HETEROGENEITY IN RAINFALL AND SOIL WATER STORAGE UNDER TREE AND CROP CANOPIES}

During the experiment there was no significant difference between the three positions in the sole crop plot in terms of either rainfall input or surface soil water content. However, van Wesenbeeck et al. (1988) showed that, under a maize canopy, the inter-row soil profile was significantly wetter than the soil directly beneath the crop. This spatial variation was attributed to differences in soil bulk density (and subsequent infiltration) caused by mechanical double-disk seeding at the time that the maize crop was planted.

In this study, as the entire ground surface was dug over prior to planting the crop, such artificial variations in bulk density should not have been present. Nevertheless, to ensure that placing the TDR sensors between crop rows neither over- or underestimated soil water content, periodic measurements of $\theta_{\mathrm{v}}$ were made 'on' and 'off' crop rows using a hand-held capacitance probe (Robinson and Dean, 1993); no significant variation in $\theta_{\mathrm{v}}$ was detected. This lack of spatial variation in $\theta_{\mathrm{v}}$ suggests that any redistribution of rainfall via stemflow by the maize plants (as observed by Parkin and Codling, 1990) was either minimal, or was compensated for by localised surface runoff, 
Table 3. Cumulative net rainfall (combined throughfall and stemflow: $\Sigma P_{n}$ ) recorded between Oct 12 and Dec 31, 1994 at various locations (see Fig. 1) below the tree and crop canopies in the $T_{d}$ and $C T_{d}$ treatments. Data are given as mm of water and $\Sigma P_{n}$ as a percentage of cumulative gross rainfall $\left(\Sigma P_{g}\right)$ during the period, which was the same as in Table 1, i.e. $512 \mathrm{~mm}$.

\begin{tabular}{lcccccc}
\hline & \multicolumn{5}{c}{ Cumulative net rainfall $\left(\Sigma P_{n}\right)$ below tree/crop canopies } \\
\hline Treatment & $\begin{array}{c}0.3 \mathrm{~m} \text { from tree } \\
(\mathrm{mm})\end{array}$ & $\begin{array}{c}1.5 \mathrm{~m} \text { from tree } \\
\left(\% P_{\mathrm{g}}\right)\end{array}$ & $(\mathrm{mm})$ & $\left(\% \Sigma P_{\mathrm{g}}\right)$ & $\begin{array}{c}2.5 \mathrm{~m} \text { from tree } \\
(\mathrm{mm})\end{array}$ & $\left(\% \Sigma P_{\mathrm{g}}\right)$ \\
\hline Sole tree $\left(\mathrm{T}_{\mathrm{d}}\right)$ & 399 & $78 \%$ & 347 & $68 \%$ & 481 & $94 \%$ \\
Tree + crop $\left(\mathrm{CT}_{\mathrm{d}}\right)$ & 421 & $82 \%$ & 312 & $61 \%$ & 469 & $92 \%$ \\
\hline $\mathrm{T}_{\mathrm{d}} / \mathrm{CT}_{\mathrm{d}}$ average & 410 & $80 \%$ & 330 & $64 \%$ & 475 & $93 \%$ \\
\hline
\end{tabular}

redistribution in the surface soil layers, and/or through soil evaporation and abstraction by crop roots.

The effect of adding trees to a cropping system, as in the case in agroforestry systems, may be to increase rainfall interception, and thereby reduce the amount of rainfall that reaches the ground and is therefore, available to the crop (Wallace et al., 1995). This makes the system more spatially complicated and makes it more difficult to model changes in surface $\theta_{\mathrm{v}}$ that result from rates of evaporation, drainage and abstraction which have been modified by the presence of trees. In this experiment, significant differences in both rainfall input and surface soil water content were observed beneath the trees, and the effect of the tree canopies on rainfall redistribution and profile water storage $(S)$ was examined. Table 3 summarises the amount of water reaching the surface at distances $0.3,1.5$ and $2.5 \mathrm{~m}$ from the tree in both the $T_{d}$ and $\mathrm{CT}_{\mathrm{d}}$ plots. Stemflow accounted for a little over $6 \%$ of incident rainfall, and was added to throughfall measurements made closest to the trees (as mentioned earlier).
Although there were slight differences between the two tree treatments, the lowest interception occurred at $2.5 \mathrm{~m}$, midway between four trees (see Fig. 1). The fact that there was any difference between $P_{g}$ and $P_{n}$ at this position suggests that, as reported in previous interception studies (Aldridge, 1975; Herwitz and Slye, 1995), some of the rainfall must have been inclined away from vertical fall paths and was therefore being intercepted by the adjacent tree canopies. $P_{n}$ was greater at $0.3 \mathrm{~m}$ distance than at $1.5 \mathrm{~m}$ (midway between two trees along the contour line) due largely to the additional soil water input from stemflow.

Figure 5 shows the variation in the amount of water stored in the top $0.4 \mathrm{~m}$ of soil as determined by TDR sensor groups located at $0.3,1.5$ and $2.5 \mathrm{~m}$ from the tree in one of the $T_{d}$ plots. Initial water storage before the onset of the rains (12 Oct 1994) was $14.2 \pm 0.8 \mathrm{~mm}, 9.8 \pm 1.1 \mathrm{~mm}$ and $24.7 \pm 0.7 \mathrm{~mm}$ at the three positions, respectively. There was a good agreement between increases in soil water storage and the ranking of interception values shown

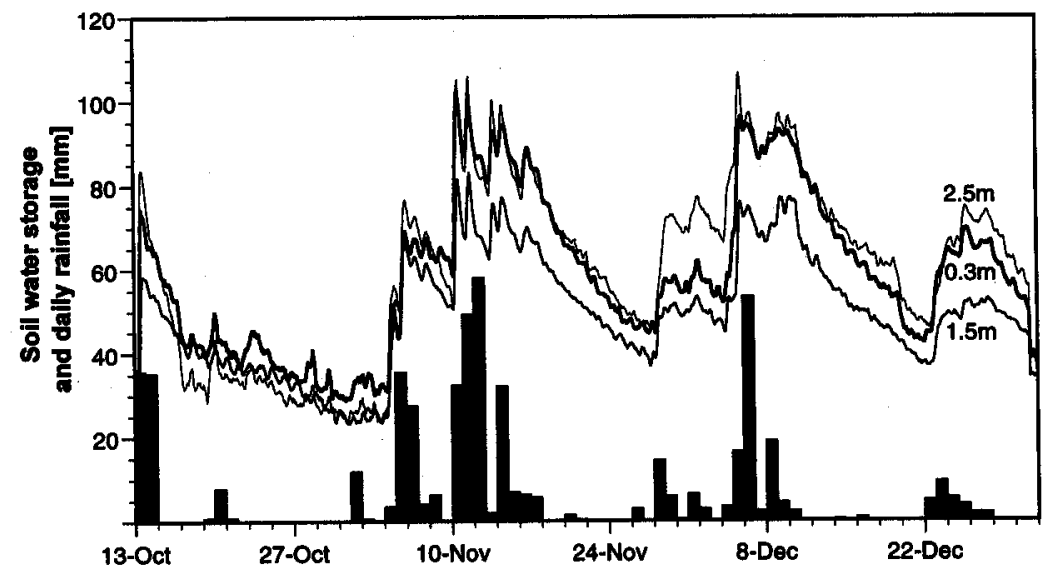

Fig. 5. Changes in the integrated water storage $(S)$ in the top $0.4 \mathrm{~m}$ soil profile in three positions in one of the CT plots between 13 Oct and $31 \mathrm{Dec}, 1994$. Data are from TDR sensors at $0.3,1.5$ and $2.5 \mathrm{~m}$ (thick to thin lines, respectively) from the base of the tree (see Fig. 1 ). Corresponding daily rainfall is shown below the TDR graph. 
in Table 3. The TDR sensor groups at $0.3 \mathrm{~m}$ and $2.5 \mathrm{~m}$ from the tree showed greater increases in storage following rainfall (ranging between 0.1 and $24.7 \mathrm{~mm} \mathrm{~h}^{-1}$ and from 0.1 to $19.8 \mathrm{~mm} \mathrm{~h}^{-1}$, respectively) than did the soil $1.5 \mathrm{~m}$ along the tree line (see Fig. 1), ranging from 0.1 to $14.2 \mathrm{~mm} \mathrm{~h}^{-1}$.

Following rainfall, the rate at which soil water content decreased was similar for both positions closer to the tree, ranging from $0.1 \mathrm{~mm} \mathrm{~h}^{-1}$ to 11.1 and $9.4 \mathrm{~mm} \mathrm{~h}^{-1}$ at $0.3 \mathrm{~m}$ and $1.5 \mathrm{~m}$, respectively. Drying rates were consistently faster at $2.5 \mathrm{~m}$ distance, ranging from 0.1 to $16.9 \mathrm{~mm} \mathrm{~h}^{-1}$. It may be that high bare soil evaporation rates at this position (Jackson and Wallace, 1999) were the driving force behind declines in soil water content.

The 'rising' and 'falling' portions of the TDR time courses were separated, in the same fashion as for Fig. 4, and are presented in Fig. 6. Substantial differences in both cumulative gains and losses of surface soil water were observed at each of the positions around the tree. Over the course of the rainy season, water storage was greatest at 2.5 $\mathrm{m}(414 \mathrm{~mm})$, and more than $150 \mathrm{~mm}$ lower $1.5 \mathrm{~m}$ along the tree line at $351 \mathrm{~mm}$. The soil directly beneath the tree

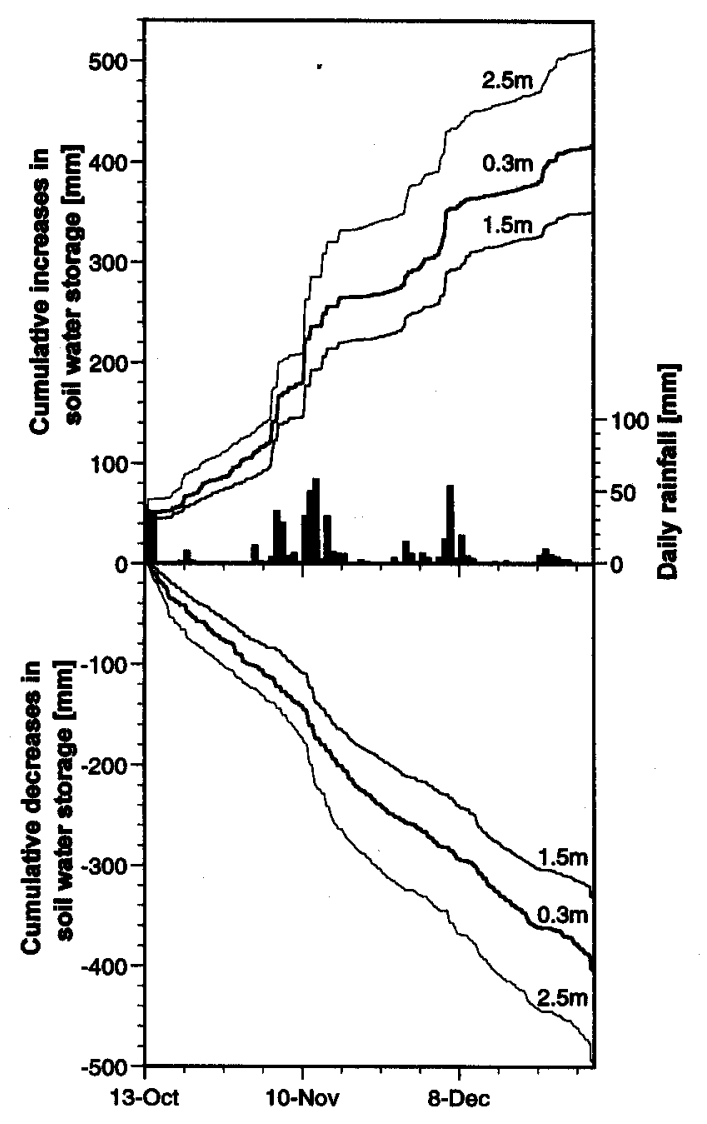

Fig. 6. Data from Fig. 5 plotted in terms of cumulative gains and losses in water against time for the TDR sensor profiles at 0.3 , 1.5 and $2.5 \mathrm{~m}$ (thick to thin lines, respectively) between 13 Oct and $31 \mathrm{Dec}$ 1994. Corresponding daily rainfall is shown below the TDR graph.
$(0.3 \mathrm{~m})$ showed cumulative water gains of $442 \mathrm{~mm}$, which suggested a significant input was made by stemflow infiltrating at the base of the tree.

Trends in cumulative losses of water reflected the differential inputs of soil water at each of the positions, with the greatest drying occurring midway between the trees at $2.5 \mathrm{~m}$. This may be due mainly to lower rates of evaporation from the shaded soil close to the tree (Jackson and Wallace, 1999), but lower root densities close to the tree (Smith et al., 1999) might have led to differences in soil water abstraction. Overall, the cumulative losses were 405 $\mathrm{mm}, 332 \mathrm{~mm}$ and $497 \mathrm{~mm}$, at $0.3,1.5$ and $2.5 \mathrm{~m}$ from the tree, respectively, with net profile storage increasing by $12 \mathrm{~mm}, 19 \mathrm{~mm}$ and $16 \mathrm{~mm}$.

The arrangement of four TDR waveguides at various depths at each location allowed a more detailed investigation of the infiltration dynamics in the Machakos soil. Figure 7 shows two examples where a wetting front devel-

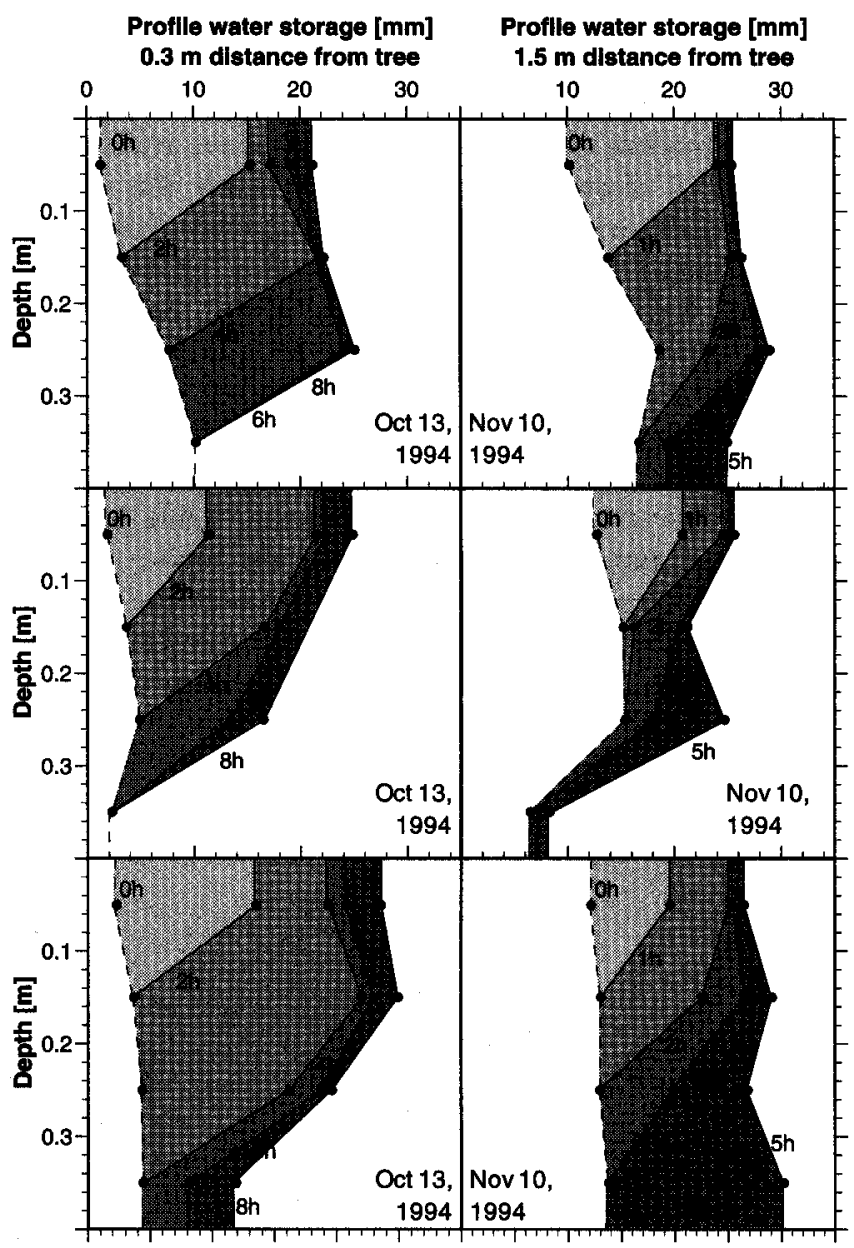

Fig. 7. Progression of soil-water storage profiles at three distances $(0.3,1.5$ and $2.5 \mathrm{~m})$ from the base of a tree in one of the sole tree $\left(T_{d}\right)$ plots during and following two rainfall events. The three graphs on the left-hand side show the development of metting fronts through relatively dry soil, while the right-hand series shows profiles that developed when the antecedent soil-water contents were higher (see Table 4). 
Table 4. Comparison of the amount of water infiltrating the soil at three distances from the base of the tree in one of the $\mathrm{CT}_{\mathrm{d}}$ plots (shown in Fig. 7) with the amount of incident rainfall as measured by the automatically logged raingauge.

\section{Rainfall event on 13-14 October 1994}

Initial values $\left(S_{i}\right)$ and cumulative changes in integrated profile water storage $(S)$ in $\mathrm{mm}$ at:

\begin{tabular}{lcccc} 
Time (h) & $\begin{array}{c}\text { Cumulative } \\
\text { rainfall }(\mathrm{mm})\end{array}$ & $\begin{array}{c}0.3 \mathrm{~m} \text { from tree } \\
22.5\left(S_{i}\right)\end{array}$ & $\begin{array}{c}1.5 \mathrm{~m} \text { from tree } \\
12.8\left(S_{i}\right)\end{array}$ & $\begin{array}{c}2.5 \mathrm{~m} \text { from tree } \\
17.3\left(S_{i}\right)\end{array}$ \\
\hline 0 & 0 & 0.0 & 0.0 & 0.0 \\
1 & 2.6 & 0.1 & 0.2 & 0.3 \\
2 & 17.4 & 15.9 & 9.5 & 13.1 \\
3 & 49.2 & 31.0 & 19.3 & 37.3 \\
4 & 66.8 & 38.8 & 23.0 & 63.5 \\
5 & 68.2 & 56.4 & 31.9 & 65.3 \\
6 & 68.8 & 52.5 & 41.9 & 65.3 \\
7 & 69.2 & 50.8 & 43.2 & 68.6 \\
8 & 70.2 & 50.0 & 45.5 & 67.9 \\
\hline
\end{tabular}

Rainfall event on 10-11 November 1994

Initial values $\left(S_{i}\right)$ and cumulative changes in integrated profile water storage $(S)$ in $\mathrm{mm}$ at:

\begin{tabular}{lcccc} 
Time $(\mathrm{h})$ & $\begin{array}{c}\text { Cumulative } \\
\text { rainfall }(\mathrm{mm})\end{array}$ & $\begin{array}{c}0.3 \mathrm{~m} \text { from tree } \\
59.3\left(S_{i}\right)\end{array}$ & $\begin{array}{c}1.5 \mathrm{~m} \text { from tree } \\
49.8\left(S_{i}\right)\end{array}$ & $\begin{array}{c}2.5 \mathrm{~m} \text { from tree } \\
52.1\left(S_{i}\right)\end{array}$ \\
\hline 0 & 0 & 0.0 & 0.0 & 0.0 \\
1 & 9.8 & 13.9 & 8.0 & 7.4 \\
2 & 22.6 & 32.4 & 13.7 & 22.7 \\
3 & 32.4 & 37.5 & 20.0 & 33.4 \\
4 & 45.5 & 43.4 & 24.0 & 41.0 \\
5 & 67.8 & 45.7 & 30.0 & 60.5 \\
\hline
\end{tabular}

ops and moves down through the $0.4 \mathrm{~m}$ profile, at $0.3,1.5$ and $2.5 \mathrm{~m}$ from the base of a tree in one of the CT $T_{d}$ plots. The first set of graphs is a typical example of the soil wetting up after a long dry period, and shows the infiltration after an overnight rainfall event of $70.2 \mathrm{~mm}$ (13-14 Oct, 94). The mean initial profile water storage $\left(S_{\mathrm{i}}\right)$ at the three positions was $17.5 \pm 4.9 \mathrm{~mm}$.

The second set of graphs represents the situation where the initial profile storage was higher (mean $S_{\mathrm{i}}=53.7 \pm 5.0$ $\mathrm{mm}$ ), and shows the infiltration following another overnight rainfall event of $67.8 \mathrm{~mm}$ (10-11 November, 1994). The duration of rainfall $(t)$ is shown for each of the profiles $(t=0,2,4,6$ and $8 \mathrm{~h}$ for the first set of graphs and $t=0,1,2,3$ and $5 \mathrm{~h}$ for the second series).

In the first case where a dry soil profile is gradually wetting up, the wetting front moved down through the soil more rapidly at $2.5 \mathrm{~m}$ from the tree than at the other two positions; after 4 hours of rainfall, the front had almost reached the bottom of the $0.4 \mathrm{~m}$ profile, and 6 hours after the rain started the sensors at the $0.35 \mathrm{~m}$ depth had detected the wetting front. In comparison, neither of the other two profiles had wetted up completely, even 8 hours after the start of the rainfall.

In the second case, where values of $S_{\mathrm{i}}$ were higher, the rates of wetting up were much faster at all three positions. As initial profile storage values were higher, less water was needed in each case to bring the soil water contents up to the values where hydraulic conductivity was sufficient for gravitational flow down through the soil to match the rainfall intensity. In this situation, the soil near the base of the tree $(0.3 \mathrm{~m})$ wetted up faster than that at $2.5 \mathrm{~m}$, although the final profiles of $S$ were quite similar 5 hours after the 
rainfall started. The soil at $1.5 \mathrm{~m}$ from the tree did not wet up to the same degree as the other two positions and the wetting front had only just reached the bottom of the profile 5 hours after the start of the rain.

Table 4 shows the changes in the integrated soil profile water storage during these two rainfall events. It summarises the data shown in Fig. 7 and demonstrates that the soil around the base of the tree $(0.3 \mathrm{~m})$ wetted up more rapidly than the soil either in line with the trees $(1.5 \mathrm{~m})$, or out in the open $(2.5 \mathrm{~m})$. The data suggest that significant amounts of water may reach and infiltrate the soil close to the tree by indirect means. Stemflow is usually believed to be of little importance when the water balance is calculated on an areal average basis. However, stemflow is not evenly distributed over the area beneath a tree canopy but often concentrates significant quantities of water (Prebble and Stirk, 1980) and nutrients (Belsky et al., 1993) into a small area around the base of a tree.

It is possible that the observed differences during each event in transmission zone water content between the various positions may be explicable in terms of different infiltration rates, and therefore the hydraulic conductivity needing to be attained in order for gravitational flow to match rainfall input. Such differences in infiltration rate and soil bulk density might result from the presence of tree roots, as reported by Zinke (1961) and Eschner (1967).

\section{Concluding remarks}

The choice of time domain reflectometry using buriable waveguides in this experiment provided the means to follow the spatial and temporal variations in surface soilwater content $\left(\theta_{\mathrm{v}}\right)$ and storage $(S)$. From the trends observed, and accepting the restrictions imposed by limited replication, the data suggest that significant differences in recharge may develop when trees are incorporated into an existing cropping system.

The data presented here form part of a larger dataset combining deep profile measurements (Jackson et al., 1999) soil evaporation (Jackson and Wallace, 1999; Wallace et al., 1999) and rainfall interception (Jackson, 1999), which, when taken together, suggest that trees in agroforestry systems may be able to utilise water resources that would otherwise be lost during intervals between cropping seasons, through soil evaporation and drainage.

When considering a spatially heterogeneous system like this, it is important to realise that the heterogeneity exists not just in two dimensions, but in three, taking into account both the crops and upperstorey tree species. The combination of interception measurements and the TDR technique in a small study like this, has demonstrated how variation in soil-water inputs across the area between trees can be measured. Further experiments with greater degrees of replication are required to shed more light on this matter.

\section{Acknowledgements}

This publication is an output from a research project ( $\mathrm{R} 4853$ and R6364) funded by the Forestry Research Programme of the Department for International Development of the United Kingdom. However the Department for International Development can accept no responsibility for any information provided or views expressed. The assistance of Dr James Lott from the University of Nottingham, and Mr Boniface Muli and Mr Peter Muia Mbatha from the ICRAF Machakos Field station is greatly appreciated.

\section{References}

Aldridge, R., 1975. The resultant direction and inclination of rainfall at Arahura, Wairarapa, New Zealand. 7. Hydrol. (N.Z.), 14, 55-63.

Baker, J.M. and Spaans, E.J.A., 1994. Measuring water exchange between soil and atmosphere with TDR-microlysimetry. Soil Sci, , 158, 22-30.

Belsky, A.J., Mwonga, S.M., Amundson, R.G., Duxbury, J.M. and Ali, A.R., 1993. Comparative effects of isolated trees on their undercanopy environments in high- and low-rainfall savannas. F. Appl. Ecol., 30, 143-155.

Breshears, D.D., Rich, P.M., Barnes, F.J. and Campbell, K., 1997. Overstory-imposed heterogeneity in solar radiation and soil moisture in a semiarid woodland. Ecol. Applications, 7, 1201-1215.

Coelho, F.E. and Or, D., 1996. A parametric model for twodimensional water uptake intensity by corn roots under drip irrigation. Soil Sci. Soc. Am. 7., 60, 1039-1049.

Davis, J.L. and Chudobiak, W.J., 1975. In-situ meter for measuring relative permittivity of soils. Paper 75-1A, 75-79, Geol. Survey Canada, Ottawa.

Eschner, A.R., 1967. Interception and soil moisture distribution. In: International Symposium on Forest Hydrology (Ed. by Sopper and Lull), pp 191-200. Pergamon Press, UK.

Heimovaara, T.J., 1993. Design of triple-wire time domain reflectometry probes in practice and theory. Soil Sci. Soc. Am. 7., 57, 1410-1417.

Herwitz, S.R and Slye, R.E., 1995. Three-dimensional modelling of canopy tree interception of wind-driven rainfall. 7 . Hydrol., 168, 205-226.

Huxley, P.A., Pinney, A. and Gatama, D., 1989. Development of agroforestry research methodology aimed at simplifying the study of potential tree/crop mixtures. Final Report on Project No. 1-432-60005613. April 1989, ICRAF, Nairobi, Kenya. 109 pp.

ICRAF, 1995. The 1994 annual report of the International Centre for Research in Agroforestry (ICRAF). Nairobi, Kenya. (H. van Houten ed.) 239 pp.

Jackson, N.A., 1999. Measured and modelled rainfall interception loss from an agroforestry system in Kenya. Agric. For. Meteorol. (in press).

Jackson, N.A. and Wallace, J.S., 1999. Soil evaporation measurements in an agroforestry system in Kenya. Agric. For. Meteorol. 94, 45-57.

Jackson, N.A., Wallace, J.S. and Ong, C.K., 1999. Tree pruning as a means of controlling water use in an agroforestry system in Kenya. Forest Ecol. Manage. 126, (in press).

Kibe, J.M., Ochung', H. and Macharia, P.N., 1981. Soils and 
vegetation of the ICRAF experimental farm (Machakos district)-Kenyan Ministry of Agriculture soil survey. Report No. D23. 68pp.

Ladekarl, U.L., 1998. Estimation of soil water balance in a Danish oak stand from measurements of soil moisture using TDR. For. Ecol. Manage., 104, 227-238.

Ledieu, J.P., DeRidder, P., DeClerk, P. and Dautrebande, S., 1986. A method of measuring soil moisture by time-domain reflectometry. F. Hydrol., 88, 319-328.

Lott, J.E., Black, C.R. and Ong, C.K., 1997. Resource utilisation by trees and crops. Agric. For. Sys. Final technical report to the Forestry Research Programme, DFID, 81 pp.

Nyberg, L., 1996. Spatial variability of soil water content in the covered catchment at Gardsjon, Sweden. Hydrol. Proc., 10, 89-103.

Ong, C.K., Corlett, J.E., Singh, R.P. and Black, C.R., 1991. Above and below ground interactions in agroforestry systems. For. Ecol. Manage., 45, 45-47.

Parkin, T.B. and Codling, E.E., 1990. Rainfall distribution under a corn canopy-implications for managing agrochemicals. Agron. 7., 82, 1166-1169.

Prebble, R.E. and Stirk, G.B., 1980. Throughfall and stemflow on silverleaf ironbark (Eucalyptus melanophloia) trees. Australian 7. Ecol., 5, 419-427.

Robinson, M. and Dean, T.J., 1993. Measurement of near surface soil water content using a capacitance probe. Hydrol. Proc., 7, 77-86.

Scott, R.M., Webster, R. and Lawrence, C.J., 1971. A land system atlas of Western Kenya. Military Vehicles and Engineering Establishment, Christchurch, Hampshire, UK.

Skaling, W., 1992. TRASE: a product history. In : Advances in measurement of soil physical properties : bringing theory into practice. Soil Science Society of America special publication no. 30.

Smith, D.M., Jackson, N.A., Roberts, J.M. and Ong, C.K., 1999. Root distributions in a Grevillea robusta-maize agroforestry system in semi-arid Kenya. Plant and Soil 211, 191-205

SoilMoisture Equipment Corp., 1991. Operating manual for the Trase $^{\mathrm{TM}}$ 6050XI TDR system. 53pp.
Toky, O.P. and Bisht, R.P., 1992. Observations on the rooting patterns of some agroforestry trees in an arid region of northwestern India. Agrofor. Systems, 18, 245-263.

Topp, G.C., Davis, J.L. and Annan, A.P., 1980. Electromagnetic determination of soil water content : Measurement in coaxial transmission lines. Wat. Resour. Res., 16, 574-582.

Topp, G.C. and Davis, J.L., 1985. Measurement of soil water content using time domain reflectometry (TDR): a field evaluation. Soil Sci. Soc. Am. 7., 49, 19-24.

Topp, G.C., 1992. The measurement and monitoring of soil water content by TDR. In: Soil moisture modelling. Proceedings of NHRC workshop, March 1992. Geological Survey of Canada. pp 155-161.

van Wesenbeeck, I.J. and Kachanoski, R.G., 1988. Spatial and temporal distribution of soil water in the tilled layer under a corn crop. Soil Sci. Soc. Am. 7., 52, 363-368.

Wallace, J.S., 1991. The measurement and modelling of evaporation from semiarid land. In: Soil Water Balance in the Sudano-Sahelian Zone (Proc. Niamey Workshop, February 1991) (Ed. by M.V.K. Sivakumar, J.S. Wallace, C. Renard and C. Giroux), 131-148. IAHS Pub. no. 199.

Wallace, J.S., Jackson, N.A. and Ong, C.K., 1995. Water balance of agroforestry systems on hillslopes. Final report to the ODA Forestry Research Programme. Institute of Hydrology report ODA 95/10. 39 pp.

Wallace, J.S., Jackson, N.A. and Ong, C.K., 1999. Modelling soil evaporation in an agroforestry system in Kenya. Agric. For. Meteorol. 94, 31-44.

Zegelin, S.J., White, I. and Russell, G.F., 1992. A critique of the Time Domain Reflectometry technique for determining field soil-water content. In: Advances in measurement of soil physical properties: bringing theory into practice. Soil Science Society of America. Special publication no. 30.

Zhai, R., Kachanoski, R.G. and Voroney, R.P., 1990. Tillage effects on the spatial and temporal variations in soil water. Soil Sci. Soc. Am. 7., 54, 186-192.

Zinke, P.J., 1961. Patterns of soil properties developed under the influence of forest trees. XI International Botanical Congress, vol. II, pp. 1641-1646. 